\title{
Particulate Matter and Noise Impact Studies of Waste Rock Dump*
}

\author{
K. J. Bansah
}

Bansah, K. J. (2016), "Particulate Matter and Noise Impact Studies of Waste Rock Dump", Ghana Mining

Journal, Vol. 16, No. 1, pp. 60 - 67.

\begin{abstract}
Adansi Gold Company Limited identified an economically viable gold deposit at Nkran in the Amansie West District of Ghana. Mining of this deposit requires the disposal of waste rock materials at a proposed waste rock dump near Nkran and Koninase communities. Since particulates and noise emissions from the operational activities at the dump are inevitable, it becomes necessary to conduct particulates and noise impact studies. The potential impact of particulates and noise from the proposed Nkran waste rock dump on the Koninase and Nkran communities were studied. Baseline TSP, PM10 and noise data were collected over a period of 14 days at the various monitoring locations in the communities. Since the period was characterised by dry weather conditions, TSP (mainly road-induced) were generally higher than permissible levels. PM10 and noise levels compared well with acceptable limits. Results of air quality modelling suggest that occupiers of building structures at Koninase and Nkran may not be affected by particulate emission from the waste dump. However, sound pressure level modelling indicates that the waste rock dump has a potential to alter background noise levels at Koninase and Nkran. Thus, conducting site-specific induction to raise awareness, use of noise bund or green buffers (vegetation) among other recommended strategies would control ambient noise levels.
\end{abstract}

Keywords: Particulates, Noise, Air Pollution, Mining, Waste dump

\section{Introduction}

In mining, materials that do not meet cut-off grade are discarded in order to gain access to those of economic value. These uneconomic materials (waste) are disposed of at waste dumps. Mining of the Nkran pit by Adansi Gold Company Limited (AGCL) requires disposal of waste rock at a waste dump around the Nkran and Koninase communities. Operations at the waste dump require the utilization of heavy equipment including dump trucks that haul materials from the pit to the dump; bulldozers to move and spread the waste material to achieve the required gradient and sometimes motor graders to clear the haul road of fallen materials. These activities generate noise and particulates (Bansah and Amegbey, 2012).

Particulate matter consists of complex and varying mixtures of microscopic particles suspended in air. These particles are found everywhere, but high concentrations and/or specific types of particles present serious danger to human health (Anon, 2011). When inhaled, the particles evade the respiratory system's natural defences and lodge deep in the lungs causing lung diseases. Research has indicated the health implications of exposure to certain levels of particulates (Bascom, 1996; Colucci, et al., 2006; Dockery, 2001; Jansen et al., 2005). Numerous epidemiologic studies have shown the adverse health effects of particle pollution (Gan, et al., 2004; Gauderman et al., 2004; Gielen, et al., 1997; Pope, 1999; Yu et al., 2000). Disasters such as the Donora smog (in Pennsylvania, 1948), where almost half of the towns' 14,000 residents became ill and 20 died instantly and the London smog in 1952, where the death toll climbed to over 10,000 are indications of the dangers of air pollution. Particle pollution can also damage the environment, alter the aesthetic value of buildings, corrode materials, alter local weather, cause haze and reduce visibility (Anon, 2002a).

Activities such as haulage of materials, dumping, clearing and levelling at the waste dump are potential sources of particulate pollution. Bansah (2009) identified gold mining as a major source of particulate pollution in the Tarkwa township of Ghana. Particulate pollution studies must be conducted for every proposed mine to ensure that activities associated with the mining operations are in compliance with required air quality criteria and also obtain data for trend analysis, regulation evaluation, and planning.

Noise, which is often defined as "unwanted or objectionable sound", affects millions of people worldwide on daily basis (Basrur, 2000). Noise pollution adversely affects the lives of people (Anon, 2011). Problems related to noise include stress related illnesses, high blood pressure, speech interference, hearing loss, sleep disruption, and lost productivity (Ising and Kruppa, 2004; Maschke et al., 2002, 1998, 1995; Pulles, et al., 1990).

Research has shown that exposure to constant or high levels of noise can cause countless adverse health effects (Anon, 2011). Surface mines mainly generate noise from overburden excavation, loading and dumping, and transport. Noise levels 
generally must be controlled to allow nearby land owners to relax or sleep comfortably during evening hours, and also protect the hearing of employees.

It is therefore, important to conduct noise and particle impact studies in order to predict potential noise and particulates levels at the Nkran and Koninase communities. These studies will help establish remediation techniques if the levels predicted are found to be undesirable.

\section{Resources and Methods Used}

Particulate and noise monitoring facilities were used to acquire particulates and environmental noise data. Total suspended particulates (TSP) and Particulates less than $10 \mu \mathrm{m}$ (PM10) data were collected using the EPAM 5000 particulate air sampling equipment and Osiris air sampler. Environmental noise monitoring was conducted with sound level meters. The coordinates of the sampling points were taken with a handheld geographic position system (GPS). Community consultative meetings with the chiefs and elders of the various receptor communities were also conducted. The meetings discussed the purpose of the study and paved way for community acceptance. Air dispersion and noise modelling were also done as part of the studies. The following sections provide details of the data collection procedure, results and discussions.

\section{Results and Discussion}

\subsection{Particulates Monitoring}

A 24 hour Total Suspended Particulates (TSP) and Particulates less than $10 \mu \mathrm{m}$ (PM10) monitoring were conducted using the EPAM 5000 particulate air sampling equipment and Osiris air sampler at the proposed Nkran waste rock dump of AGCL and surrounding communities. The monitoring period was characterised by severe dry weather conditions. Fig. 1 shows the monitoring locations while Fig. 2 summarizes mean TSP and PM10 concentrations at the monitoring locations. The monitoring stations at the waste dump were sited at the side closest to the communities.

The Environmental Protection Agency of Ghana (EPA) recommends TSP guideline values of 150 $\mu \mathrm{g} / \mathrm{m}^{3}$ and $230 \mu \mathrm{g} / \mathrm{m}^{3}$ for residential areas and mine environments respectively, while acceptable PM10 limit is $70 \mu \mathrm{g} / \mathrm{m}^{3}$. TSP concentrations at the various monitoring locations were mostly higher than acceptable. PM10 levels generally, compared well with permissible limits. The high TSP levels could be attributed to road-induced dust. The period under study was characterised by harsh dry weather conditions which aided the ability of disintegrated rock material to easily become airborne. Substantial bush burning activities (by farmers) at the proposed waste dump location during the period could also be a major source of particulates.

\subsection{Particulates Dispersion Modelling}

Dispersion modelling uses mathematical models to characterize the atmospheric processes that disperse a pollutant emitted by a source (Anon, 2011). Based on emissions and meteorological inputs, a dispersion model is used to predict concentrations at selected downwind receptor locations. Meteorological inputs in air dispersion modelling consist of physical parameters that are measured directly by instrumentation.

There was no established weather monitoring station capable of capturing meteorological data at Adansi Gold during the study period. However, a one-year meteorological data was obtained from the Environmental Department of Keegan Resources, the closest weather monitoring location, about $14 \mathrm{~km}$ from Adansi Gold. The data collected included wind speed, wind direction, temperature and rainfall. Fig. 3 shows the relative locations of AGCL and Keegan Resources.

The wind speed and wind direction data were used to generate a wind rose and illustrated in Fig. 4. Conventionally, a wind rose shows the direction from which the wind blows. However, for the purpose of this study and easy understanding and appreciation, the wind rose shown in Fig. 4 illustrates the direction to which the wind blows. It could be observed from Fig. 4 that about $55 \%$ of the time, the wind blows in the east direction, making the east, predominant wind direction in the study area.

The wind rose was then superimposed on the map of the study area to determine which occupiers of building structures within the study area will be affected by particle pollution. It is observed from Fig. 5 that particulates emitted from the waste dump would not be blown towards the communities. Consequently, building structures and inhabitants of the settlements may not be affected by particulates emitted at the Nkran waste dump. It is worth noting however, that building structures close to the unpaved Koninase-Nkran road would mainly be exposed to road-induced dust.

To mitigate any potential conflict due to particulates, dust control by water suppression is highly recommended for such section of road to reduce the impact of road-induced dust, as occupiers may not be able to distinguish between road-induced particulates and particulates emitted from the waste dump. Dust suppression using water bowsers should also be practiced on the haul road leading to the waste dumps to control dust from the haul road. It is also possible to practice wet loading 
of waste rock to further ensure that dumping does not generate dust.

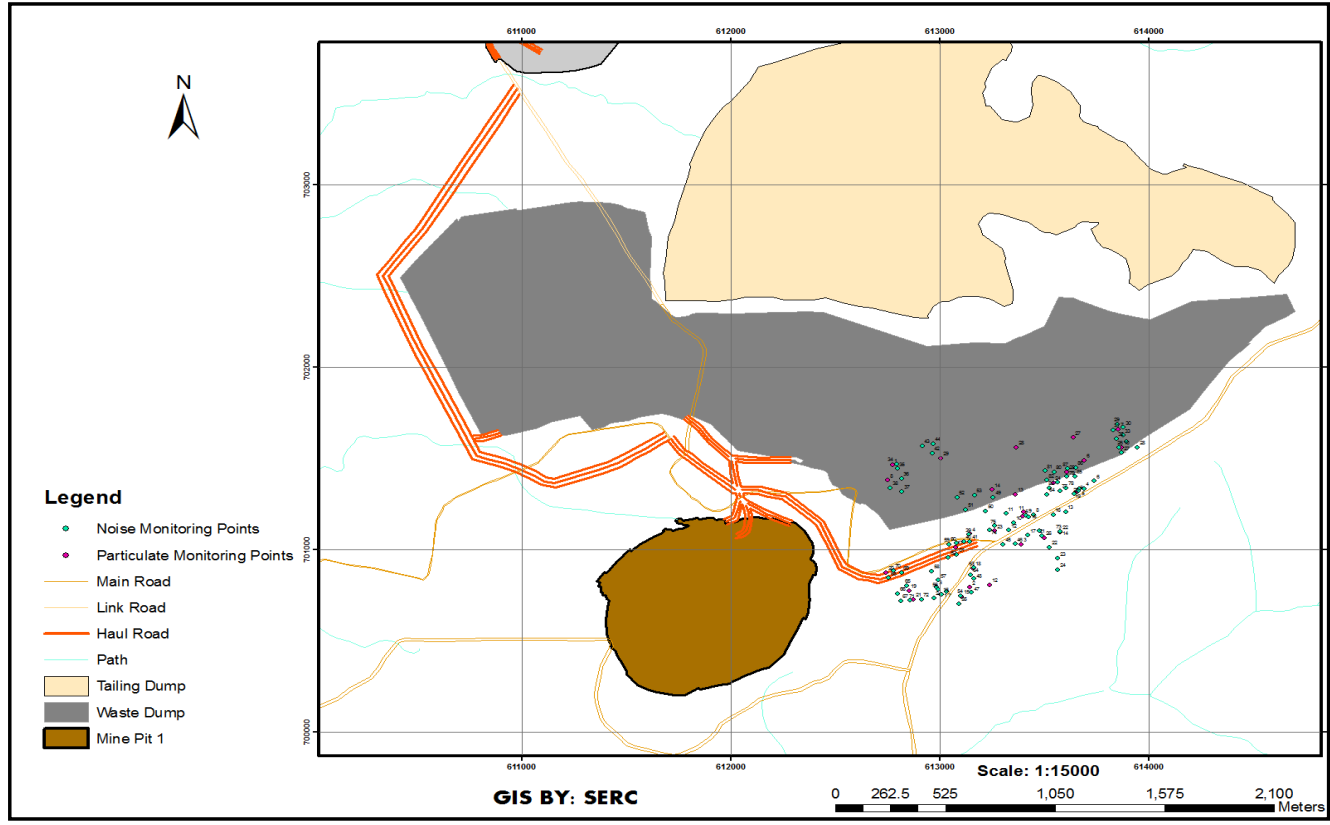

Fig. 1 Particulate and Noise Monitoring Locations

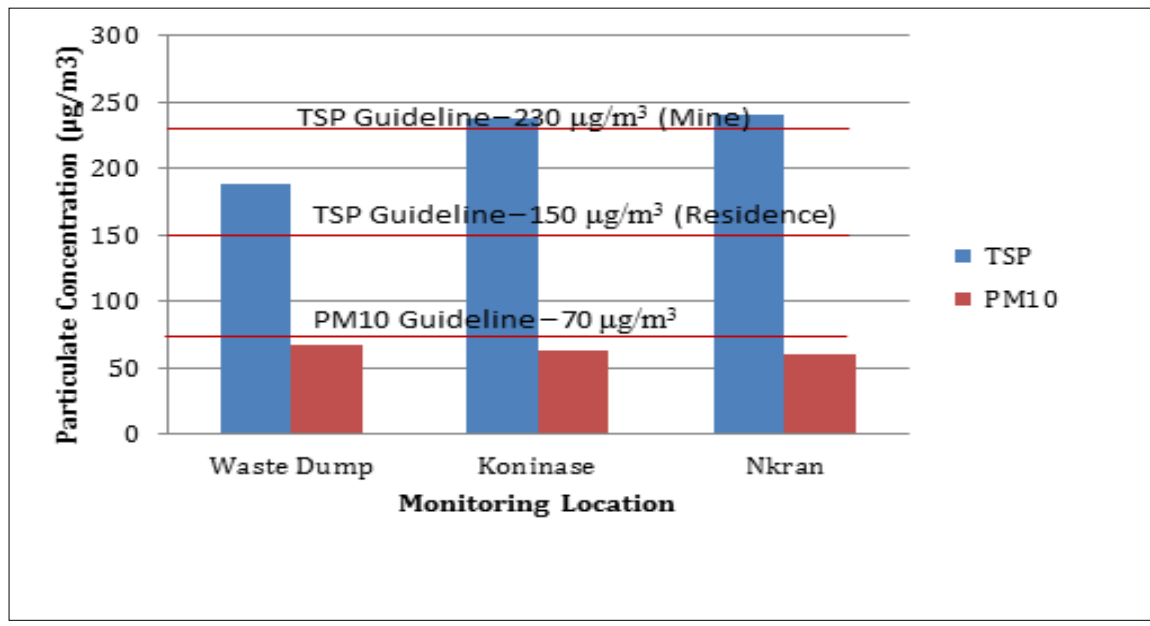

Fig. 2 Mean Particulates Concentrations

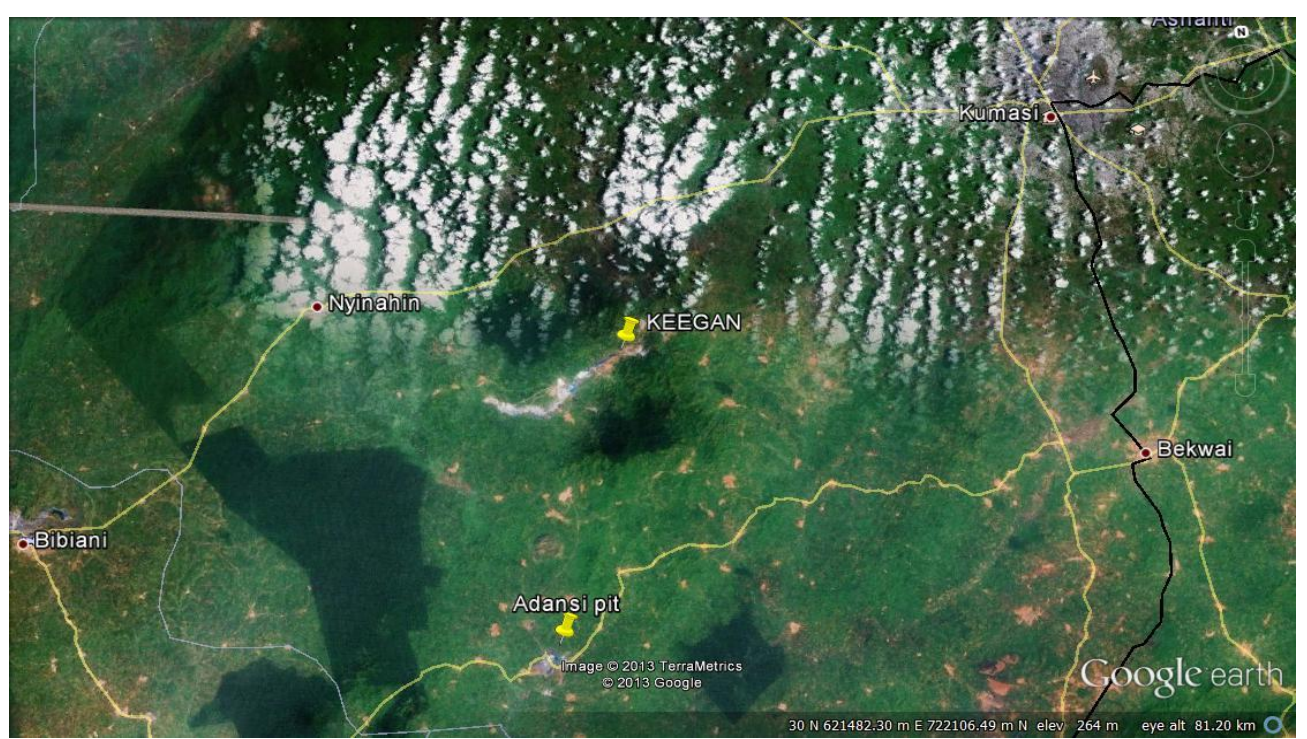


Fig. 3 Location of AGCL and Keegan Resources

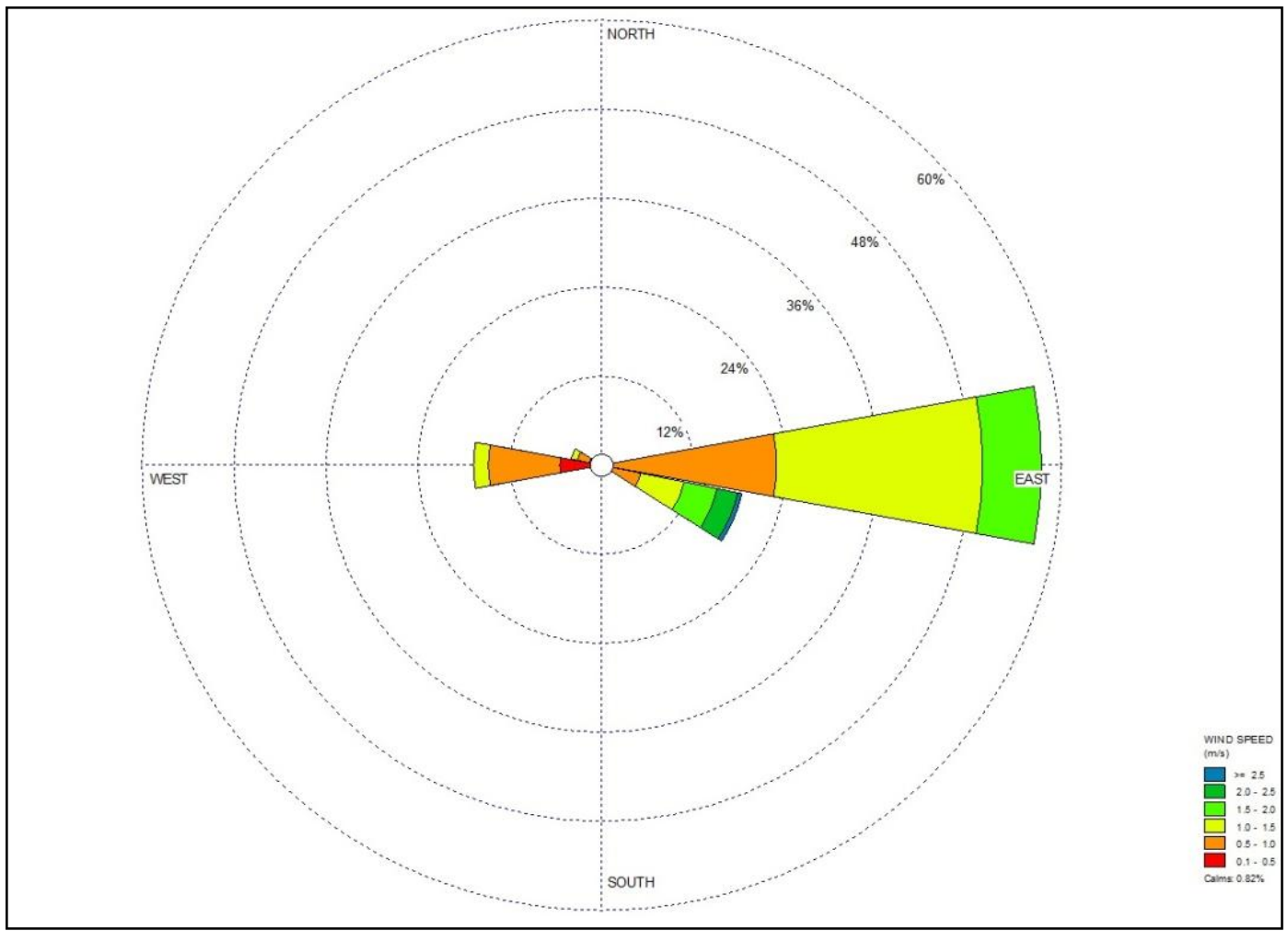

Fig. 4 Wind Rose for AGCL (Jan - Dec 2012)

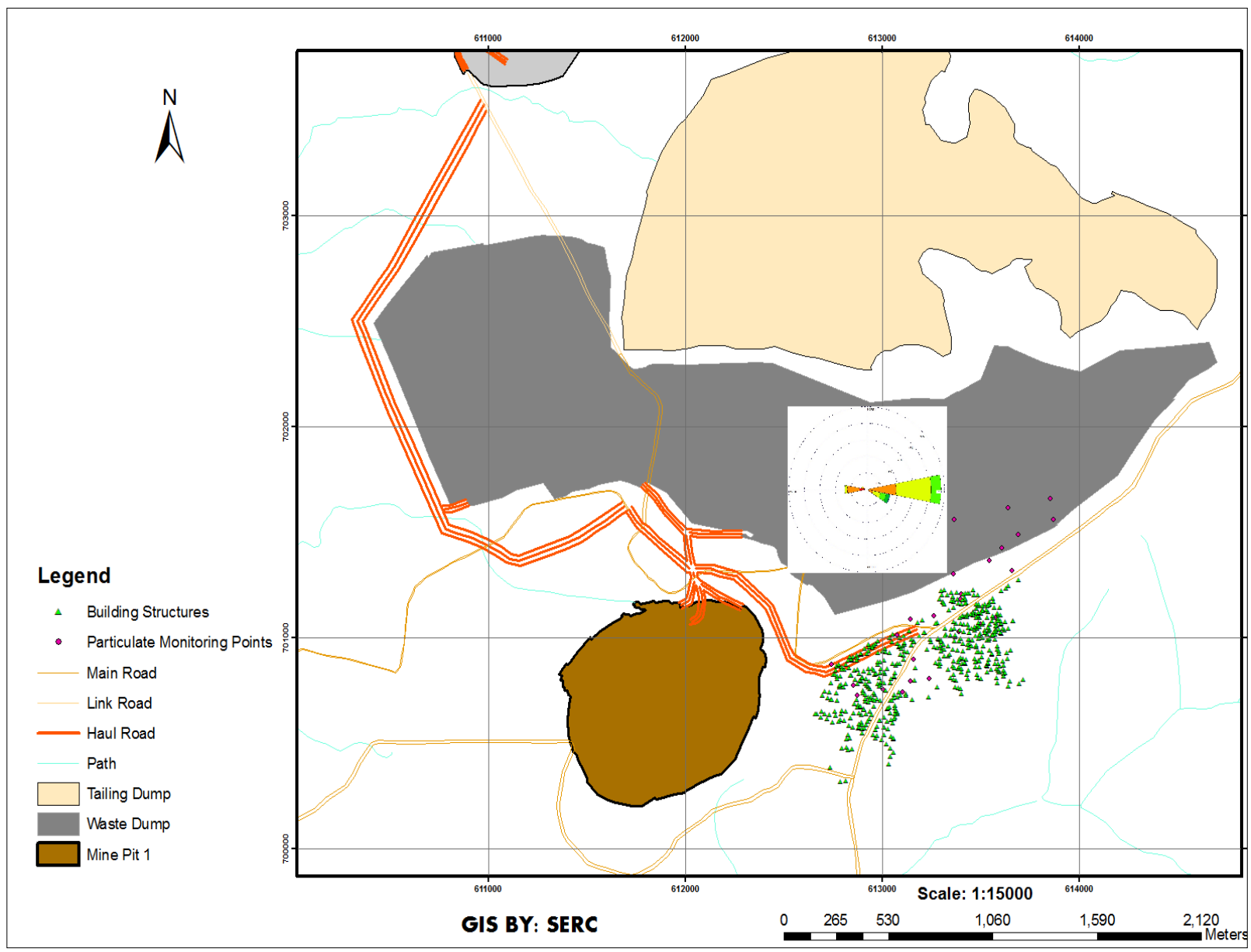

Fig. 5 Map of Study Area with Superimposed Wind Rose 


\subsection{Noise Monitoring}

Noise monitoring was carried out with sound level meters at the waste dump and surrounding communities. The monitoring activity was categorized into two: "Day" (6:00am to 10:00pm) and "Night" (10:00pm and 6:00am) monitoring in accordance with EPA criteria. The monitoring locations fall within Zone B2 of the EPA criteria with permissible noise levels of $60 \mathrm{dBA}$ and 55 dBA for "Day" and "Night" respectively. Fig. 6 presents the noise levels at the monitoring locations.

The mean noise levels at the monitoring locations fall below permissible limits. It is also observed that the noise levels at the waste dump are lowest compared to that of Koninase and Nkran. This situation was expected, as there were little noiseinducing activities at the proposed waste dump. Sources of noise in the communities are mainly from vehicular movements, motor bicycles and domestic activities.

\subsection{Sound Pressure Level Modelling}

Sound pressure level (SPL) modelling was conducted to predict noise levels that may propagate from the waste dump to residents of Koninase and Nkran communities. The major sources of noise at the proposed Nkran waste dump include Cat 777D dump truck, Cat D10/D11 track dozer, and motor grader 16M. Warrior et al. (2006) suggest that the noise level measured $10 \mathrm{~m}$ away from Cat $777 \mathrm{D}$ truck is $91 \mathrm{~dB}(\mathrm{~A})$. While noise level generated by motor grader $16 \mathrm{M}$ is $72 \mathrm{~dB}(\mathrm{~A})$ (Anon, 2013), noise level by Cat D10/D11 track dozer is also $72 \mathrm{~dB}(\mathrm{~A})$ measured $15 \mathrm{~m}$ away from the plant (Anon, 2010). Assuming two Cat 777D trucks operating simultaneously at the waste dump, the noise levels were combined with the highest baseline noise level measured at the proposed waste dump to obtain a total of $94 \mathrm{~dB}(\mathrm{~A})$. The sound pressure level $\mathrm{Lp}_{2}$ at a distance $\mathrm{r}_{2}$ from the source (waste dump) was then estimated using Equation 1.

$$
L p_{2}=\mathrm{Lp}_{1}-20 \log \frac{r_{2}}{r_{1}}-A e_{1,2}
$$

Where $\mathrm{Lp}_{1}$ is the sound pressure level measured at location 1 (waste dump), $\mathrm{Ae}_{1,2}$ is attenuation along path $r_{2}-r_{1}$ between location 1 and 2, and represents factors affecting sound propagation. Such factors include atmospheric absorption, ground attenuation, wind or temperature gradient, trees, barriers or buildings (Anon, 2002b). As a rule of thumb SPL is reduced by $6 \mathrm{~dB}(\mathrm{~A})$ when the distance from the source is doubled in free field conditions. As a conservative estimate, a value of 5 $\mathrm{dB}(\mathrm{A})$ to $5.5 \mathrm{~dB}(\mathrm{~A})$ is used to account for ground reflections. Using equation 1 , and assuming $\mathrm{Ae}_{1,2}=$ $6 \mathrm{~dB}(\mathrm{~A})$, noise levels that may be propagated from the waste dump were estimated and shown in Table 1.

The predicted noise levels were higher than permissible within a distance of $250 \mathrm{~m}$ from the waste dump. There are however, some residents within $60 \mathrm{~m}$ from the dump. These resident may be exposed to as much as about $74 \mathrm{~dB}(\mathrm{~A})$, which exceeds EPA criteria of $60 \mathrm{~dB}(\mathrm{~A})$ for "Day" and 55 $\mathrm{dB}(\mathrm{A})$ for "Night". Applying a noise bund with an efficiency of $40 \%$ (assumed) will reduce the noise levels to acceptable levels. The result of the noise modelling with noise bund introduced is also presented in Table 1.

The predicted noise levels without a noise bund at the periphery of the waste dump is illustrated in Fig. 7. The buffers are created at $100 \mathrm{~m}$ interval. All residents within the red buffer may be exposed to higher than permissible levels of noise. Fig. 8 illustrates predicted noise levels with the environmental noise bund in place. It could be observed that the introduction of the noise bund would cause a significant reduction in noise levels in the settlements. The use of green buffers (vegetation) can equally be adopted for noise screening.

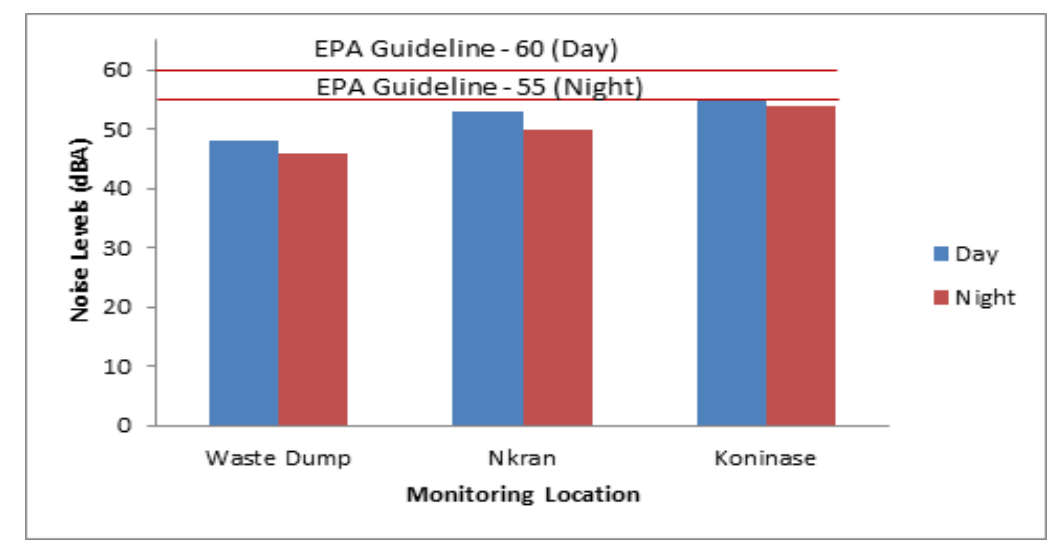


Fig. 6 Mean Noise Levels at Monitoring Locations

Table 1 Predicted Noise Levels

\begin{tabular}{|c|c|c|}
\hline Distance from Source (m) & Predicted Noise Levels(dBA) & $\begin{array}{c}\text { 40\% Reduction Efficiency by } \\
\text { Bund(dBA) }\end{array}$ \\
\hline 50 & 74 & 44 \\
\hline 100 & 68 & 41 \\
\hline 150 & 64 & 39 \\
\hline 200 & 62 & 37 \\
\hline 250 & 60 & 36 \\
\hline 300 & 58 & 35 \\
\hline 350 & 57 & 34 \\
\hline 400 & 56 & 33 \\
\hline 450 & 55 & 32 \\
\hline 500 & 54 & 32 \\
\hline 550 & 53 & 31 \\
\hline 600 & 52 & 31 \\
\hline 650 & 52 & 31 \\
\hline 700 & 51 & 30 \\
\hline 750 & 50 & 30 \\
\hline 800 & 50 & 30 \\
\hline 850 & 49 & 29 \\
\hline 900 & 49 & 29 \\
\hline 950 & 48 & 29 \\
\hline 1000 & 48 & \\
\hline & & \\
\hline
\end{tabular}

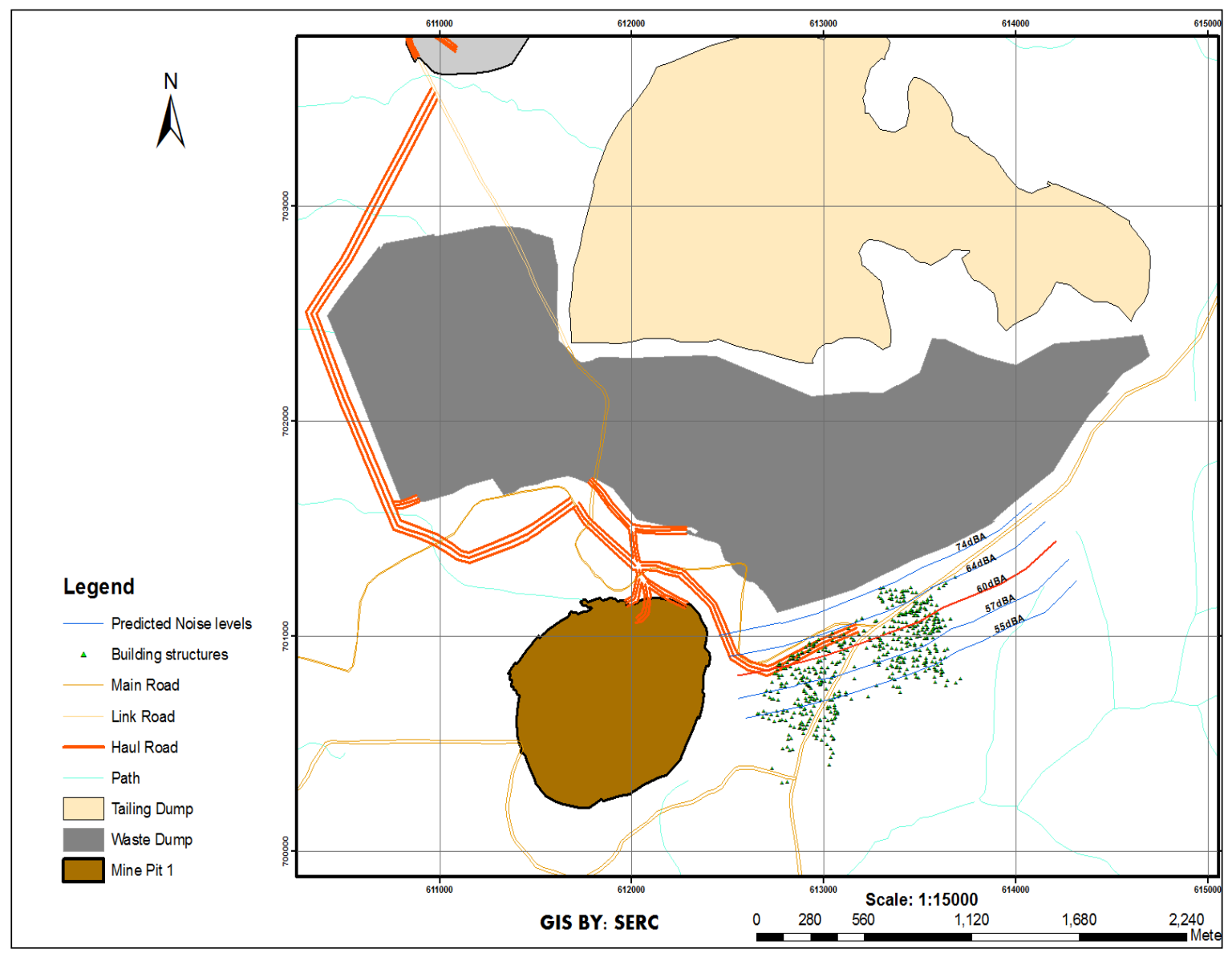

Fig. 7 Predicted Noise Levels (Waste Dump without Noise Bund at the Periphery) 


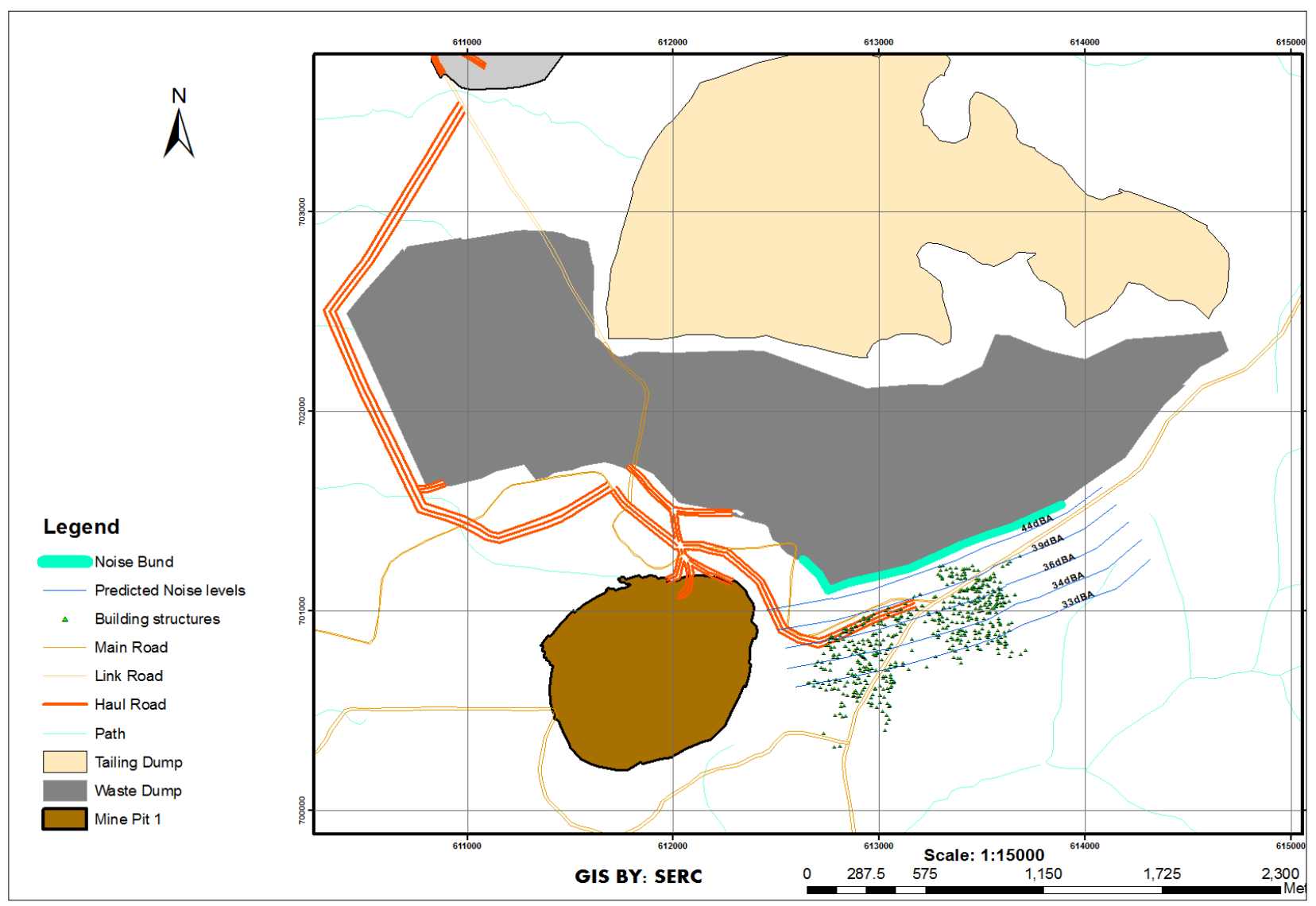

Fig. 8 Predicted Noise Levels (Waste Dump with Noise Bund at the Periphery)

\section{Conclusions}

The primary objective of this study was to predict airborne particulates and noise impacts of the proposed Nkran waste rock dump on surrounding communities. Air and noise monitoring were conducted at the proposed waste dump, and the Nkran and Koninase communities. The results of the monitoring were used to conduct air quality and noise modelling. Analysis of the results suggests that particulates emitted at the waste dump would be blown away from the dump in the east direction, insofar as the predominant wind direction remains east. Thus, occupiers of building structures would not be affected by particle emission from the waste dump. Road-induced dust was found to be the major source of particulates in the Nkran and Koninase communities. Noise prediction studies revealed that activities at the proposed waste dump have the potential to alter ambient noise levels at Koninase. Occupants of building structures within $50-100 \mathrm{~m}$ from the dump may be affected by noise emission.

To mitigate potential conflict due to particulates, dust suppression by water should be conducted regularly on the Koninase-Nkran road, as residents may not be able to distinguish between road- induced dust and particulates emitted from the waste dump. Also, constructing environmental noise bund or planting trees and shrubs that have thick waxy leaves, dense evergreen foliage and branches that extend to the ground (as recommended by the Georgia Forestry Commission) along the south-eastern periphery of the waste dump would shield/screen Koninase residents from noise emitted at the waste dump. Additionally, AGCL should ensure that the quietest equipment available is used at the waste dump. Conducting site-specific induction to raise awareness could further reduce particulates and noise emission. Continuous ambient noise monitoring should also be conducted at the waste dump and surrounding communities to ensure that noise levels are kept below acceptable limits.

\section{Acknowledgements}

The supports offered by staff of Adansi Gold Company Limited, SERC Limited and AERC during the data acquisition period are well acknowledged.

\section{References}


Anon, (2013), “Cashman Equipment”, www.cashman equipment.co, Accessed: February 28, 2013.

Anon, (2011), "Particulate and Noise Pollution", United States Environmental Protection Agency Webpage, www.epa.gov, Accessed: February 28, 2013

Anon, (2010), "D10 Track Type Tractor", www.cat.com, Accessed: February 28, 2013.

Anon, (2002a), "Air Pollution, United States Environmental Protection Agency Webpage", www.epa.gov, Accessed: September, 2009.

Anon, (2002b), "Sound Attenuation" Silex, 16pp.

Bansah, K. J and Amegbey, N. (2012), "Ambient Particulate Matter Monitoring and Analysis- A Case Study", Research Journal of Environmental and Earth Sciences, Maxwell Scientific Organization, Vol. 4, No. 4, pp. 419423.

Bansah, K. J. (2009), “Ambient Particulate Matter Monitoring and Analysis - A Case Study of GoldFields Ghana Limited, Tarkwa", MPhil Thesis Report, University of Mines and Technology, Tarkwa, 72 pp.

Bascom, R. (1996), "Committee of the Environmental and Occupational Health Assembly of the American Thoracic Society", Health Effects of Outdoor Air Pollution, Am J Respir Crit Care Med., 153:3-50.

Basrur, S. V. (2000), "Health Effects of Noise, City of Toronto Community and Neighbourhood Services", Toronto Public Health, Health Promotion and Environment Protection Office, 24pp.

Colucci M. E.,Veronesi, L, Roveda A. M., Marangio E., Sansebastiano, G. (2006), "Particulate Matter (PM10) Air Pollution, Daily Mortality, and Hospital Admissions: Recent Findings", Ig Sanita Pubbl., 2006 May-Jun; 62(3):289-304.

Dockery D. W. (2001), "Epidemiologic Evidence of Cardiovascular Effects of Particulate Air Pollution", Environ Health Perspect, 109:483486.

Gan, W. Q., Man, S. F., Senthilselvan, A., Sin, D. D. (2004), "Association between Chronic Obstructive Pulmonary Disease and Systemic Inflammation: A Systemic Review and a MetaAnalysis", Thorax, 59:574-580.

Gauderman W. J., Avol, E., Gilliland, F., Vora, H., Duncan, T., Berhane, K., et al. (2004), "The Effect of Air Pollution on Lung Development from 10 to 18 years of Age", N Engl J Med, 351:1057-1067.

Gielen M. H., Van Der Zee, S. C., Van Wijnen, J. H., Van Steen, C. J., Brunkreef, B. (1997), "Acute Effects of Summer Air Pollution on Respiratory Health of Asthmatic Children", Am J Respir Crit Care Med, 1997; 155:2105-2108.

Ising, H., Kruppa, B. (2004), "Health Effects caused by Noise: Evidence in the Literature from the Past 25 Years", Noise \& Health: A
Bimonthly Inter-disciplinary International Journal, Vol. 6, Issue 22, pp. 5-13.

Karen L. Jansen, Timothy V. Larson, Jane Q. Koenig, Therese F. Mar, Carrie Fields, Jim Stewart, Morton Lippmann (2005), "Associations between Health Effects and Particulate Matter and Black Carbon in Subjects with Respiratory Disease", Environmental Health Perspectives, 113(12): 1741-1746.

Maschke, C., Harder, J., Ising, H., Hecht, K., Thierfelder W. (2002), "Stress Hormone Changes in Persons under Simulated Night Noise Exposure", Noise \& Health, 5(17): 3545.

Maschke, C., Harder, J., Hecht, K., Balzer, H. U. (1998), "Nocturnal Aircraft Noise and Adaptation. Noise Effects", 7th International Congress on Noise as a Public Health Problem 2: 433-438.

Maschke, C., Arndt, D., Ising, H. (1995), "Nachtlicher Fluglarm und Gesundheit: Ergebnisse von Labor- und Feldstudien", Bundesgesundhbl, 38, 4 (1995) 130-137.

Pope, C. A., 3rd, Hill, R. W., Villegas, G. M. (1999), "Particulate Air Pollution and Daily Mortality on Utah's Wasatch Front", Environ Health Perspect, 107:567-573.

Pulles, M. P. J., Biesiot, W., Stewart, R. (1990), "Adverse Effects of Environmental Noise on Health: An Interdisciplinary Approach", Environment International, Vol. 16, Issues 4-6, pp. 437-445.

Yu, O., Sheppard, L., Lumley, T., Koenig, J. Q., Shapiro, G. G.(2000), "Effects of Ambient Air Pollution on Symptoms of Asthma in SeattleArea Children enrolled in the CAMP Study", Environ Health Perspect, 108:1209-1214.

Warrior, R., Gregg, C. and Dowdall, M. (2006), "Reduction of Noise and Dust from Surface Mining Plants", The Banks Group, Presentation to the North of England Institute of Mining and Mechanical Engineers and the Institute of Materials, Minerals and Mining, 11pp.

\section{Authors}

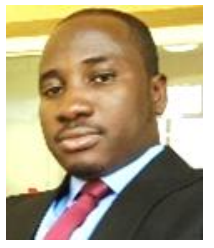

Kenneth J. Bansah is a Graduate Research Assistant and $\mathrm{PhD}$ Candidate at Missouri University of Science and Technology, Missouri, USA. He holds an MPhil Degree in Mining Engineering from the University of Mines and Technology, Ghana and BSc. (First Class) in Mining Engineering from the Kwame Nkrumah University of Science and Technology, Ghana. Since July 2010, Kenneth has been the Director and Chief Consultant of Safety \& Environmental Research Consultancy Limited providing consulting services in environmental and safety issues. His current research areas include blast optimization, artisanal and small scale mining, environmental and engineering applications of geophysics, occupational health and hygiene, safety and environmental issues. 